\title{
Erratum to: Mephedrone and methylenedioxypyrovalerone (MDPV), major constituents of "bath salts," produce opposite effects at the human dopamine transporter
}

Krasnodara Cameron • Renata Kolanos •

Rakesh Vekariya • Louis De Felice •

Richard A. Glennon

Published online: 14 March 2013

(C) Springer-Verlag Berlin Heidelberg 2013

Erratum to: Psychopharmacology

$$
\text { DOI 10.1007/s00213-013-2967-2 }
$$

The original version of this article inadvertently contained a mistake. The third author name was misspelled as "Rakesh Verkariya" when it should be "Rakesh Vekariya".

The online version of the original article can be found at doi:http://dx.doi.org/ 10.1007/s00213-013-2967-2.

K. Cameron $\cdot$ L. De Felice $(\bowtie)$

Department of Physiology and Biophysics, School of Medicine, Virginia Commonwealth University, Richmond, VA 23298, USA

e-mail: ljdefelice@vcu.edu

R. Kolanos $\cdot$ R. Vekariya $\cdot$ R. A. Glennon $(\bowtie)$

Department of Medicinal Chemistry, School of Pharmacy, Virginia

Commonwealth University, Richmond, VA 23298, USA

e-mail: glennon@vcu.edu 